\title{
PENGARUH SENAM ERGONOMIK TERHADAP PENURUNAN KADAR GULA DARAH PADA LANSIA DENGAN DIABETES MELITUS DI DESA SIDAKARYA, DENPASAR SELATAN
}

\author{
Ni Putu Mira Febrianti ${ }^{1}$ I Putu Artha Wijay ${ }^{2}$, Alfiery Leda Kio ${ }^{3}$ \\ STIKES Bina Usada Bali ${ }^{123}$ \\ e-mail:3alfierykio@yahoo.co.id
}

\begin{abstract}
Diabetes mellitus is a chronic metabolic disorder caused by pancreas that does not produce enough insulin, resulting on the inability of the body to use insulin effectively. The symptoms suffered by patients are often mild and this causes considerable people with diabetes mellitus do not realize that they have diabetes mellitus. If Diabetes Mellitus is not immediately treated, it would cause long-term complication including macrovascular diseases. Plentiful elderly with Diabetes Mellitus in Sidakarya Village do not realize that they suffer from Diabetes Mellitus and prefer to do non-pharmacological therapy. One of non-pharmacological therapies that can reduce blood sugar levels is ergonomic exercises. The aim of this study was to find out how ergonomic exercises effected towards the lower of blood sugar levels in elderly in Sidakarya Village, South Denpasar. This study is a quantitative research using Pre-Experimental Design One Group Pre-Test Post-Test with total samples of 19 elderly. Data was analysed using non-parametric test of Wilcoxon Sign Rank Test in order to compare the result of the pre-test and post-test. The result of this study showed that prior to the implementation of ergonomic exercises, it was found approximately 57,9\% respondents who suffered from prediabetes and $42,1 \%$ respondents who suffered from diabetes, while after intervention of ergonomic exercises were given, there were only 7 respondents $(36,8 \%)$ who suffered from diabetes and 12 respondents $(63,2 \%)$ who have normal blood sugar levels. According to the calculation result, it was obtained that $p$ value $=0,0001<\alpha 0,05$ and Zcount $-3.824^{b}$ that showed an effect of ergonomic exercises towards the lower of blood sugar levels in elderly in Sidakarya Village, South Denpasar. Based on the result of this study, ergonomic exercises is expected to be able to help reducing blood sugar levels in elderly with Diabetes Mellitus who prefer to do non-pharmacological therapy.
\end{abstract}

Keywords: diabetes mellitus, elderly, ergonomic exercise

\begin{abstract}
ABSTRAK
Diabetes mellitus adalah gangguan metabolisme kronis yang disebabkan oleh pankreas yang tidak menghasilkan cukup insulin, sehingga tubuh tidak dapat menggunakan insulin secara efektif. Gejala yang diderita pasien seringkali ringan dan hal ini menyebabkan cukup banyak penderita diabetes mellitus tidak menyadari bahwa dirinya menderita diabetes mellitus. Jika Diabetes Mellitus tidak segera diobati, akan menyebabkan komplikasi jangka panjang termasuk penyakit makrovaskular. Banyaknya lansia penderita Diabetes Mellitus di Desa Sidakarya tidak menyadari bahwa dirinya menderita Diabetes Mellitus dan lebih memilih untuk melakukan terapi nonfarmakologi. Salah satu terapi nonfarmakologi yang dapat menurunkan kadar gula darah adalah senam ergonomis. Penelitian ini bertujuan untuk mengetahui pengaruh senam ergonomis terhadap penurunan kadar gula darah pada lansia di Desa Sidakarya Denpasar Selatan. Penelitian ini merupakan penelitian kuantitatif dengan menggunakan Pre-Experimental Design One Group Pre-Test Post-Test dengan jumlah sampel 19 lansia. Data dianalisis menggunakan uji non parametrik Wilcoxon Sign Rank Test untuk membandingkan hasil pre-test dan post-test. Hasil penelitian ini menunjukkan bahwa sebelum pelaksanaan senam ergonomis ditemukan sekitar $57,9 \%$ responden yang menderita pradiabetes dan $42,1 \%$ responden yang menderita diabetes, sedangkan setelah diberikan intervensi senam ergonomis terdapat hanya 7 responden $(36,8 \%)$ yang menderita diabetes dan 12 responden $(63,2 \%)$ yang memiliki kadar gula darah normal. Berdasarkan hasil perhitungan diperoleh nilai $p$ value $=0,0001<\alpha 0,05$ dan Zhitung $-3,824 \mathrm{~b}$ yang menunjukkan adanya pengaruh senam ergonomis terhadap penurunan kadar gula darah pada lansia di Desa Sidakarya Denpasar Selatan. Berdasarkan hasil penelitian ini, senam ergonomis diharapkan dapat membantu menurunkan kadar gula darah pada lansia penderita Diabetes Mellitus yang lebih memilih untuk melakukan terapi nonfarmakologi.
\end{abstract}

Kata kunci: diabetes mellitus, lansia, senam ergonomik 


\section{PENDAHULUAN}

Lansia merupakan tahap akhir siklus hidup manusia, merupakan bagian dari proses kehidupan yang tak dapat dihindarkan dan akan dialami oleh setiap individu. Pada tahap ini individu mengalami banyak perubahan baik secara fisik maupun mental, khususnya kemunduran dalam berbagai fungsi dan kemampuan yang pernah dimilikinya (Pribadi Agus, 2015). Lansia mengalami masalah kesehatan yang meliputi kemunduran dan kelemahan baik kemunduran fisik, kognitif, perasaan, mental, dan social. Perubahan fisik yang terjadi pada lanjut usia sangat bervariasi, dan terjadi di berbagai sistem, yaitu system integumen, sistem kardiovaskuler, sistem gastrointestinal, sistem reproduksi, sistem neurologis, sistem perkemihan, dan sistem muskuloskeletal (Malo et al., 2019)

Hasil riskesdas tahun 2013, penyakit terbanyak pada lanjut usia adalah penyakit tidak menular yaitu salah satunya antara lain diabetes melitus. Data untuk masalah Kesehatan lanjut usia tentang penyakit diabetes melitus untuk kategori umur 55-64 tahun terdapat 5,5\%, untuk kategori umur 65-74 tahun terdapat $4,4 \%$ dan untuk kategori umur $>75$ tahun terdapat 3,5\% (Faisal et al., 2018)

Sesuai data International Diabetes Federation (IDF) tahun 2015, jumlah penyandang diabetes mellitus (DM) di dunia sekitar 415 juta, dan diperkirakan meningkat menjadi sekitar 642 juta (55\%) di tahun 2040 . Indonesia merupakan negara urutan ke 7 dari 10 negara dengan jumlah penyandang DM terbanyak di dunia yaitu sekitar 10 juta penduduk dan di perkirakan tahun 2030 di indonesia jumlah penderita diabetes yaitu 21,3 juta orang (PERKENI, 2019). Di bali pada tahun 2013 sebanyak 39.885 orang yang menderita diabetes mellitus (Infodatin-Diabetes.Pdf, n.d.). Di kota Denpasar pada tahun 2018 sekitar 9.123 penderita DM, tetapi di targetkan sebanyak 2.312 $(2,5 \%)$ sudah mendapatkan pelayanan kesehatan (Dinkes, 2018).

Diabetes mellitus merupakan suatu kelompok penyakit metabolik dengan karakteristik hiperglikemia yang terjadi karena kelainan sekresi insulin, kerja insulin atau kedua-duanya. Di negara berkembang telah terjadi pergeseran penyebab kematian utama yaitu dari penyakit menular ke penyakit tidak menular. (Ariani et al., 2015). Diabetes mellitus (DM) atau disebut diabetes saja merupakan penyakit gangguan metabolic menahun akibat pankreas tidak memproduksi cukup insulin atau tubuh tidak dapat menggunakan insulin yang diproduksi secara efektif. Insulin adalah hormone yang mengatur keseimbangan kadar gula darah. Akibatnya terjadi peningkatan konsentrasi glukosa didalam darah (hiperglikemia).

Tindakan keperawatan yang bisa dilakukan untuk memodifikasi pada keluarga yang menderita diabetes adalah dengan melakukan aktivitas fisik misalnya olah raga. Olahraga sangat efektif dalam pengaturan kadar glukosa darah adalah senam. Salah satu penanganan supaya gula darah stabil dilakukan olahraga salah satunya adalah senam ergonomik. (Ariani et al., 2015)

Melihat kondisi tersebut penanganan diabetes melitus perlu dilakukan setelah deteksi dini untuk mengurangi komplikasi. Sejak tahun 50 - 60 tahun yang lalu dikenal 3 cara utama penatalaksanaan penyakit DM yaitu diet, obat - obatan dan olahraga. Senam Ergonomik atau senam inti raga adalah teknik senam untuk mengembalikan atau membetulkan posisi dan kelenturan sistem saraf dan aliran darah pada kaki diabetes, memaksimalkan supply oksigen ke otak, membuka sistem kecerdasan, sistem keringat, sistem pemanas tubuh, sistem pembakaran asam urat, kolesterol, gula darah, asam laktat, christal oxalate, sistem konversi karbohidrat, sistem pembuatan elektrolit atau ozon dalam darah, sistem kebugaran dan sistem kekebalan tubuh dari energi negatif/ virus, serta sistem pembuangan energi negative dari dalam tubuh. (Tri Susilowati, 2016)

Senam ergonomik adalah senam fundamental yang gerakannya sesuai dengan susunan dan fungsi fisiologis tubuh. Senam ergonomik merupakan kombinasi dari gerakan otot dan pernafasan. Senam ergonomik dapat mencegah dan mengobati berbagai penyakit karena saat melakukan senam ergonomik terjadi penurunan kadar gula darah. Penurunan kadar gula darah ini dapat terjadi karena saat melakukan senam ergonomik otot-otot digerakkan secara optimal sehingga lebih banyak menyerap gula darah untuk proses pembakaran. (Ariani et al., 2015).

Hasil penelitian (Ariani et al., 2015) Penulis menganalisa bahwa setelah dilihat dari hasil dan didukung oleh penelitian terkait, latihan jasmani mempunyai efek yang baik terhadap penurunan kadar gula darah dibukutikan dari hasil persentase sebelum dan sesudah dilakukan senam egonomik. Sesudah dilakukan senam ergonomik sebagian besar responden mengalami penurunan kadar gula darah. Diabetes mellitus merupakan suatu penyakit yang sangat mematikan dan banyak masyarakat yang tidak sadar atau tidak peduli dengan diabetes mellitus. Dengan senam ergonomik ini kadar gula darah dapat dikontrol. Dari hasil penelitian rata-rata kadar gula darah sebelum diberikan senam ergonomik adalah 201,65 mg/dl dengan standar devisiasi 16,865, sedangkan rata-rata skor kadar gula darah setelah diberikan senam ergonomik adalah 173,86 mg/dl dan standar devisiasi 20,512.

Hasil studi pendahuluan yang peneliti lakukan di Puskesmas I Denpasar Selatan, didapatkan data lansia yang menderita diabetes melitus Desa Sidakarya Denpasar Selatan didapatkan data 19 lansia yang mengalami diabetes mellitus dan lansia yang menderita diabetes mellitus lebih banyak memilih untuk melakukan pengobatan non farmakologi atau tradisional. Berdasarkan latar belakang diatas peneliti tertarik untuk mengetahui apakah ada pengaruh senam ergonomik terhadap penurunan kadar gula darah pada lansia di Desa Sidakarya Denpasar Selatan. 


\section{Vol. 16 No.2 Mei - Agustus 2021}

\section{METODE}

Penelitian ini adalah penelitian kuantitatif dengan menggunakan metode Pre-Experimental Design. Penelitian ini menggunakan rancangan OneGroup Pretest-posttest Design. Pengambilan sampel teknik non-probability yaitu purposive sampling, didapatkan sampel sebanyak 19 orang dengan kriteria inklusi dan eksklusi. Data dianalisis menggunakan uji statistic Wilcoxon Sign Rank Test.

HASIL

\section{Karakteristik Responden}

Tabel 1 Karakteristik berdasarkan Usia

\begin{tabular}{lll}
\hline Usia & Frekuensi & Persentase \\
\hline $60-65$ & 16 & 79,2 \\
\hline $66-70$ & 3 & 15,8 \\
\hline Total & 19 & 100,0 \\
\hline
\end{tabular}

Berdasarkan tabel 1 menunjukkan bahwa responden lansia penderita diabetes melitus terbanyak berusia 6065 tahun berjumlah 16 responden dengan persentase $79,2 \%$.

Tabel 2 Karakteristik Berdasarkan Jenis Kelamin

\begin{tabular}{lll}
\hline Jenis Kelamin & Frekuensi & Persentase \\
\hline Perempuan & 12 & 63,2 \\
\hline Laki-laki & 7 & 36,8 \\
\hline Total & 19 & 100,0 \\
\hline
\end{tabular}

Data yang diperoleh dari tabel 2 menunjukan bahwa 12 responden dengan persentase 63,2 \% lebih banyak diderita oleh perempuan.

Tabel 3 Karakteristik Responden Berdasarkan Pendidikan

\begin{tabular}{lcl}
\hline Pendidikan & Frekuensi & Persentase \\
\hline SD & 14 & 73,7 \\
\hline SMP & 5 & 23,3 \\
\hline Total & 19 & 100,0 \\
\hline
\end{tabular}

Tabel 3 menunjukan bahwa 14 responden dengan persentase $73,3 \%$ paling banyak Pendidikan terakhir SD.

\section{Analisis Univariat \\ Gambaran nilai gula darah Pada Lansia di Desa Sidakarya, Denpasar Selatan Sebelum Melakukan Senam Ergonomik.}

Tabel 4 Gambaran Diabetes melitus Pada Lansia di Desa Sidakarya, Denpasar Selatan Sebelum Melakukan Senam Ergonomik

\begin{tabular}{lll}
\hline Kategori & Frekuensi & Persentase \\
\hline $\begin{array}{l}\text { Pre Diabetes } \\
140-199 \mathrm{mg} / \mathrm{dL}\end{array}$ & 11 & 57,9 \\
\hline $\begin{array}{l}\text { Diabetes } \\
>200 \mathrm{mg} / \mathrm{dL}\end{array}$ & 8 & 42,1 \\
\hline Total & 19 & 100,0 \\
\hline
\end{tabular}

Berdasarkan hasil tabel 4 terdapat responden yang mengalami pre-diabetes sebanyak 11 responden $(57,9 \%)$ dan yang mengalami diabetes 8 responden $(42,1 \%)$.

Gambaran Diabetes Melitus Pada Lansia di Desa Sidakarya, Denpasar Selatan Sesudah Melakukan Senam Ergonomik

Tabel 5 Gambaran Diabetes Melitus Pada Lansia di Desa Sidakarya, Denpasar Selatan Sesudah Melakukan Senam Ergonomik

\begin{tabular}{lll}
\hline Kategori & Frekuensi & Persentase \\
\hline $\begin{array}{l}\text { Normal } \\
<140 \mathrm{mg} / \mathrm{dL}\end{array}$ & 12 & 63,2 \\
\hline $\begin{array}{l}\text { Pre-Diabetes } \\
140-199 \mathrm{mg} / \mathrm{dL}\end{array}$ & 7 & 36,8 \\
\hline Total & 19 & 100,0 \\
\hline
\end{tabular}

Berdasarkan hasil tabel 5 terdapat sebanyak 12 responden $(63,2 \%)$ mengalami penurunan gula darah menjadi normal, sedangkan masih tersisa 7 responden $(36,8 \%)$ yang mengalami pre diabetes

\section{Analisis Bivariat}

Hasil Analisis Pengaruh Senam Ergonomik Terhadap Penurunan Kadar Gula Darah Pada Lansia

Tabel 6 Analisis pengaruh senam ergonomic (Wilcoxon Signed Rank Test)

\begin{tabular}{llll}
\hline Hasil & $\mathbf{N}$ & $\mathbf{P}_{\text {value }}$ & $\mathbf{Z}_{\text {hitung }}$ \\
\hline Pre test- Post test & 19 & 0,001 & $-3.824^{\mathrm{b}}$ \\
\hline
\end{tabular}

Berdasarakan hasil tabel 6 hasil statistik Wilcoxon Sign Rank Test didapatkan skor nilai setelah melakukan senam lansia jumlah responden yang mengalami penurunan gula darah semakin meningkat, hal ini menunjukan setelah diberikan intervensi sebanyak 19 reponden mengalami penurunan gula darah. Dari hasil perhitungan di peroleh nilai $\mathrm{P}_{\text {value }}=0,001<\alpha 0,05$ yang menunjukkan ada pengaruh senam ergonomik terhadap penurunan kadar gula darah pada lansia penderita diabetes di Desa Sidakarya, Denpasar Selatan 


\section{KESIMPULAN}

\section{PEMBAHASAN}

\section{Karakteristik Responden Berdasarkan Usia}

Hasil penelitian yang telah dilakukan jumlah responden yang menderita diabetes melitus lebih banyak berkisar antara usia 60-65 tahun dengan jumlah 16 dari 19 responden $(79,2 \%)$. Usia adalah indikator untuk menentukan kedewasaan dalam melakukan pengambilan keputusan berdasarakan pengalaman, mayoritas penderita diabetes melitus paling banyak dialami oleh orang-orang yang berusia 60 tahun ke atas.

Hal ini disebabkan karena tingkat sensitifitas insulin mulai menurun sehingga kadar gula darah yang seharusnya masuk ke dalam sel akan tetap berada di aliran darah yang menyababkan kadar gula darah meningkat dan semakin meningkat usia banyak terjadi perubahan pada organ pancreas yang memproduksi insulin yang mengakibatkan terjadinya penurunan fungsi kerja pancreas Santosa et al ( 2017).

\section{Karakteristik Responden Berdasarkan Jenis Kelamin}

Hasil penelitian ini menunjukan menunjukan bahwa 12 dari 19 responden $(63,2 \%)$ menunjukkan bahwa penderita diabetes melitus lebih banyak diderita oleh lansia perempuan. Setelah usia 65 tahun. Banyaknya jumlah penderita diabetes melitus dari kaum perempuan disebabkan karena perempuan lebih berisiko terkena DM dibandingkan laki- laki, hal ini dikarenakan perempuan mempunyai peluang lebih besar pada peningkatan indeks masa tubuh, sindrom siklus bulanan, pasca menstruasi lemak tubuh menjadi mudah terakumulasi akibat proses hormonal tersebut sehingga wanita lebih berisiko menderita $\mathrm{dm}$ Nazriati et al (2018)

Secara teori menyatakan bahwa diabetes melitus lebih banyak diabalmi oleh perempuan dri pada laki-laki hal tersebut di karenakan pada perempuan kadar kolesterol HDL, LDL, dan trigliserida lebih tinggi di bandingkan pada laki-laki.

\section{Karakteristik Responden Berdasarkan Pendidikan}

Faktor lain yang mempengaruhi kenaikan kadar gula darah adalah pendidikan. Berdasarkan menunjukkan bahwa sebagain besar responden berpendidikan SD sebanyak 14 responden $(73,7 \%)$. Tingkat Pendidikan juga mempengaruhi, Pendidikan seseorang menentukan kemudahan seseorang dalam mengelola informasi setiap pembaharuan informasi serta pengaplikasian sebuah informasi yang baru dan Pendidikan seseorang merupakan factor yang berpengaruh pada seseorang penderita diabetes untuk dapat mengatur dan memahami dirinya dalam mengobati diabetes melitus yang dialami Lara \& Hidajah ( 2017).
Berdasarkan hasil penelitian dan pembahasan diatas dari 19 responden maka dapat disimpulkan ada pengaruh senam ergonomik terhadap penurunan kadar gula darah pada lansia di desa sidakarya, Denpasar selatan $(p$ value $=0,001<\alpha 0,05)$. Diharapkan dengan adanya penelitian ini dimanfaatkan sebagai pedoman bagi perawat dalam terapi komplementer untuk mengatasi masalah diabetes pada lansia dengan senam ergonomik dan juga sebagai bahan masukan kepada lansia yang mengalami diabetes sehingga dapat melakukan tindakan mandiri untuk menurunkan kadar gula darah.

\section{DAFTAR PUSTAKA}

1. Ariani, R. D., Nuraeni, A., Supriyono, M., Program, D., Keperawatan, S., Depkes, P., \& Semarang, K. (2015). Efektivitas senam ergonomik terhadap penurunan kadar gula darah pada lansia di kelurahan wonosari semarang. Karya Ilmiah S1 Keperawatan, 1-8.

2. Dinkes, D. (2018). Bali, Profil Kesehatan Bali, 2018. Journal of Chemical Information and Modeling, 53(9), 1689-1699.

3. Faisal, Muzakkir, \& Maria, W. (2018). Faktor Yang Berhubungan Dengan Minat Home Care pada Lansia Penderita Diabetes Melitus di Puskesmas Sudiang Raya. Jurnal Ilmiah Kesehatan Diagnosis, 12(1), 20-27.

4. Infodatin-Diabetes.Pdf. (n.d.).

5. Jerau, E. E., Ismonah, \& Arif, S. (2016). Efektivitas Senam Kaki Diabetik Dan Senam Ergonomik Terhadap Penurunan Kadar Glukosa Darah Pasien Diabetes Melitus Di Persadia Rs Panti Wilasa Citarum. Jurnal Ilmu Keperawatan Dan Kebidanan (JIKK), 1-12.

6. Lara, A. G., \& Hidajah, A. C. (2017). Hubungan Pendidikan, Kebiasaan Olahraga, Dan Pola Makan Dengan Kualitas Hidup Lansia Di Puskesmas Wonokromo Surabaya. Jurnal PROMKES, 4(1), 59.

7. Malo, Y., Ariani, N. L., \& Firman yasin, D. D. (2019). Pengaruh Senam Ergonomis Terhadap Skala Nyeri Sendi Pada Lansia Wanita. Nursing News : Jurnal Ilmiah Keperawatan, 4(1), 190-199.

8. Meidikayanti, W., \& Wahyuni, C. U. (2017). Hubungan Dukungan Keluarga dengan Kualitas Hidup Diabetes Melitus Tipe 2 Di Puskesmas Pademawu. Jurnal Berkala Epidemiologi, 5(2), 240-252.

9. Nazriati, E., Pratiwi, D., \& Restuastuti, T. (2018). Pengetahuan pasien diabetes melitus tipe 2 dan hubungannya dengan kepatuhan minum obat di 


\section{Vol. 16 No.2 Mei - Agustus 2021}

Puskesmas Mandau Kabupaten Bengkalis. Majalah Kedokteran Andalas, 41(2), 59.

10. Nina, W. (2016). Hubungan Karakteristik Responden Dengan Risiko Diabetes Melitus Dan Dislipidemia Kelurahan Tanah Kalikedinding. Jurnal Unair, 5(1), 95-106

11. Nurmalika, L., \& Prasetiya, C. H. (2019). Senam Ergonomik Untuk Mengatasi Hiperglikemi Pada Lansia Dengan Dm Di Panti Wreda Harapan Ibu Semarang. Jurnal Manajemen Asuhan Keperawatan, 3(2), 38-43.

12. PERKENI. (2019). Pedoman Pemantauan Glukosa Darah Mandiri. Perkeni, 28 halaman.

13. Pribadi Agus. (2015). pelatihan aerobik untuk kebugaran paru jantung bagi lansia. Jurnal Olahraga Presentai, Volume 11, Nomor 2, Juli 2015 ,
14. Restyana Noor F. (2016). DIABETES MELITUS TIPE 2 Restyana. Indonesian Journal of Pharmacy, 27(2), 74-79.

15. Santosa, A., Trijayanto, P. A., \& Endiyanto. (2017). Hubungan Riwayat Garis Keturunan dengan Usia Terdiagnosis Diabetes Melitus Tipe II. Jurnal Ilmiah Kesehatan, 1-6.

16. Tri Susilowati, F. W. (2016). Senam Ergonomis Meningkatkan Sensitivitas Kaki Pada Penderita Diabetes Melitus Di Kelurahan Purwosari Kecamatan Laweyan Kota SSurakarta. Jurnal Maternity, 3(2), 71-86.

17.Zainuddin, M., Utomo, W., \& Herlina. (2015). Hubungan Stres dengan Kualitas Hidup Penderita Diabetes Mellitus Tipe 2. Jurnal Online Mahasiswa, 2(1), 890-898. 